\title{
Expression of circulating miR-200c and vascular endothelial growth factor-A (VEGF-A) mRNA as potential biomarker in human hepatocellular carcinoma
}

\author{
Nanda Qoriansas ${ }^{1}$, Dede Renovaldi ${ }^{1}$, Juwita Raditya ${ }^{1}$, Puji Lestari ${ }^{1}$, Nur Signa \\ Gumilas $^{2}$, Suharno ${ }^{2}$, Didik Setyo Heriyanto ${ }^{3}$, Neneng Ratnasari ${ }^{4}$, Sofia Mubarika ${ }^{*}$ \\ ${ }^{1}$ Magister in Biomedical Sciences, Postgraduate Program, Faculty of Medicine, Public \\ Health and Nursing, Universitas Gadjah Mada, Yogyakarta, ${ }^{2}$ Faculty of Medicine, \\ Universitas Jenderal Soedirman, Purwokerto, ${ }^{3}$ Department of Anatomic Pathology, \\ Faculty of Medicine, Public Health and Nursing, Universitas Gadjah Mada, Yogyakarta, \\ ${ }^{4}$ Department of Internal Medicine, Faculty of Medicine, Public Health and Nursing, \\ Universitas Gadjah Mada, Yogyakarta, ${ }^{5}$ Department of Histology and Cell Biology, Faculty \\ of Medicine, Public Health and Nursing, Universitas Gadjah Mada, Yogyakarta,
}

DOI: http://dx.doi.org/10.19106/JMedScie/005004201805

\section{ABSTRACT}

Hepatocellular carcinoma $(\mathrm{HCC})$ is a common liver disease that causes significant public health problems throughout the world, including in Indonesia. The HCC is the six most common cancers and second cancer-related deaths among men in the world. Recently it was reported that the microRNA is an important player in hepatocarcinogenesis. The expression of MiRNA-200c is often regulated in primary HCC and HCC cell lines. Vascular endothelial growth factor-A (VEGF-A) is a regulator of angiogenesis that has been reported as miR-200c target gene. This study was conducted to measure expression levels in miR200c and mRNAVEGF-A and their potential role as biomarkers at HCC. A total of 36 $\mathrm{HCC}$ patients and 36 healthy subjects were included in this study. The relative expression of miRNA-200c and mRNA VEGF-A was quantified using reverse transcription real time quantitative PCR (qRT PCR). Relative expression was calculated using . Unpaired t-test was used to compare the expression levels of circulating miRNA-200c and mRNA VEGF-A in HCC patients and healthy subjects. Pearson test was used to determine correlation between circulating miR-200c expression and mRNA VEGF-A expression levels. The expression levels of circulating miR-200c in HCC patients were lower compared to healthy subjects although it was not significant $(p=0.258)$. Conversely, the expression levels of circulating mRNA VEGF-A in HCC patients were significantly higher compared to healthy subjects $(p=0.001)$. The relative expression levels of circulating miR-200c were negatively correlated with mRNA VEGF-A in HCC patients. In conclusion, the expression levels of mRNA VEGF-A in HCC patients are significantly deregulated in compared to that in healthy subjects. Negative correlation between circulating miRN-200c and mRNA VEGF-A expression levels are reported in HCC patients.

\section{ABSTRAK}

Hepatocellular carcinoma (HCC) adalah penyakit hati yang umum dan menyebabkan masalah kesehatan masyarakat yang signifikan di seluruh dunia, termasuk di Indonesia. Karsinoma hepatoseluler adalah penyebab kematian keenam akibat kanker umumnya dan kedua pada laki-laki di seluruh dunia. Saat ini microRNA dilaporkan berperan penting dalam hepatokarsinogenesis. Ekspresi MiRNA-200c mengalami deregulasi pada jaringan HCC primer dan sel HVCC. Vascular endothelial growth factor-A (VEGF-A) adalah regulator angiogenesis yang dilaporkan sebagai gen target miR-200c. Penelitian ini dilakukan untuk mengkaji ekspresi miR-200c dan mRNA VEGF-A serta peran 
potensialnya sebagai biomarker HCC. Sebanyak 36 pasien HCC dan 36 subjek sehat diambil dalam penelitian ini. Ekspresi relatif mRNA miRNA-200c dan VEGF-A diukur menggunakan reverse transcription real time quantitative PCR (qRT PCR). Ekspresi relatif dihitung menggunakan. Uji t tidak berpasangan digunakan untuk membandingkan tingkat sirkulasi miRNA-200c dan mRNA VEGF-A pasien HCC dan subjek sehat. Uji Pearson digunakan untuk menentukan korelasi antara sirkulasi ekspresi miR-200c dan tingkat ekspresi mRNA VEGF-A. Tingkat ekspresi miR-200c yang bersirkulasi pada pasien HCC lebih rendah dibandingkan dengan subjek sehat meskipun tidak bermakna $(p=0.258)$. Ekspresi level sirkulasi mRNA VEGF-A lebih tinggi secara bermakna dibandingkan subjek sehat $(p=0.001)$. Tingkat ekspresi relatif miR-200c dalam sirkulasi memiliki hubungan negatif dengan VEGF-A mRNA pada pasien HCC. Dapat disimpulkan, tingkat ekspresi mRNA VEGF-A mengalami deregulasi secara bermakna pada pasien HCC dibandingkan pada subjek sehat. Ada hubungan negatif antara tingkat ekspresi miRN-200c dalam sirkulasi dan mRNA VEGF-A pada pasien HCC.

Keywords: blood plasma - hepatocellular carcinoma - miR-200c - mRNA VEGF-A biomarker

\section{INTRODUCTION}

Cancer is a non-infectious disease with significant impacts on overall morbidity and mortality in the world. ${ }^{1}$ It was estimated in 2018 there are 18 million new cancer cases, 9 million cancer associated mortality worldwide. Hepatocellular carcinoma (HCC) is the most common cause of cancer deaths in the world $(9.1 \%$ of total cancer related deaths or 746,000 in the world). ${ }^{1}$ The HCC is also one of the problems in Indonesia, especially in males, with the second average mortality rate of 12,654 people/ 5 years. It is predicted to increase due to delays in the diagnosis, limitations of diagnostic methods and treatment. ${ }^{1}$

The development of early diagnostic methods for HCC has been widely applied. However, these current methods have some limitations in the practice. ${ }^{2}$ Indonesia generally adopts the HCC diagnostic method based on the Asian-Pacific Association for the Study of the Liver (APASL). It is performed with observation of the typical vascular pattern of arterial enhancement with portal-venous washout obtained by dynamic computed tomography, dynamic magnetic resonance imaging or contrast enhanced ultrasonography. ${ }^{3}$ The achievement of 5 -year survival rate is still low only about $20 \%$ of all cases. This generally associated with late diagnosis of the HCC when the cancer has entered the advanced stage. ${ }^{4}$

MicroRNA is a class of small noncoding RNA molecule (22-24 nucleotideslong) that functions as a post-transcriptional regulator of protein coding gene expression. MicroRNA can bind to one or more mRNAs and cause the degradation and/or inhibition of protein translation. ${ }^{4}$ About $30 \%$ of protein coding genes are known to be widely regulated by microRNAs. ${ }^{5,6}$

Dysregulation of microRNA expression has been identified in a variety of human cancers. This dysregulation is associated with clinical and biological functions specific to the process of carcinogenesis included HCC. ${ }^{6,7}$ Many studies have shown that microRNA can potentially be a clinical diagnostic biomarker because it has a high degree of stability and can describe a biological change especially in cancer. ${ }^{8,9}$ MicroRNA dysregulation can be detected in several ways using tissue, serum, plasma, or urine samples. High levels of stability in extracellular microRNAs can be encountered in body fluids especially plasma. MicroRNA can be used as non-invasive markers for HCC detection, prognostic and predict therapeutic response. $^{8}$

Several microRNAs dysregulation 
contribute to the pathogenesis of HCC. One of the microRNAs dysregulation reported in HCC is the miR-200 family. MiR-200c is downregulated in HCC tissue and it is associated with low survival rate of $\mathrm{HCC}$ patients in the early stages. ${ }^{10}$ Decrease of miR-200c expression affects the expression of several oncogenes, such as Vascular Endothelial Growth Factor A (VEGF-A). An in vitro study reported VEGF-A, protein expression and cell proliferation significantly increased in $\mathrm{HCC}$ cells. ${ }^{11}$ VEGF is a class of protein growth factor that plays a role in the angiogenesis of cancer cells, not only for the development of new blood vessels but also for the development of some types of cancer tissue. ${ }^{12}$ Cancer cells produce angiogenic proteins such as VEGF that stimulates endothelial cells proliferation and migration. ${ }^{13}$ Angiogenesis widely contributes in many cancer cells growth included HCC. The vascular endothelial cells develop at this stage when the tumor lesion has exceeded $0.5 \mathrm{~mm}$. VEGF plays an important role in promoting of the endothelial cells proliferation, thus supporting neovascularization in and around cancer tissues. ${ }^{14}$ The study aimed to measure expression levels in miR-200c and mRNA VEGF-A of HCC. The results of this study will be useful in the development of these genes as biomarker candidates of HCC.

\section{MATERIALS AND METHODS}

\section{Design and sample collection}

This was a cross sectional study using plasma samples from 36 new HCC patients in Dr. Sardjito General Hospital, Yogyakarta and Prof. DR. Margono Soekarjo General Hospital, Purwokerto. As control 36 plasma samples of healthy subjects obtained from Blood Bank Center of Dr. Sardjito General Hospital, Yogyakarta were used.

The inclusion criteria for HCC patients were new diagnosed with $\mathrm{HCC}$, no history of other cancer, never received chemotherapy and radiotherapy, willing to participate in study, and the patient's clinical condition allowed to be taken his blood. The inclusion criteria for the healthy subjects were no history of $\mathrm{HCC}$ and other cancers, no family history of $\mathrm{HCC}$, age 25-70 years, $\mathrm{HBsAg}$ negative, and no $\mathrm{HBV}$ and $\mathrm{HCV}$ infection history. The exclusion criteria were resigned as the respondent, and the patient's condition did not allow for blood sampling.

\section{Total RNA extraction}

About 5-6 mL of venous blood sample were taken and put into 2 EDTA tube vacutainer and then centrifuged at $1500 \mathrm{rpm}$ for $10 \mathrm{~min}$ to obtain plasma sample. The plasma was then stored in the refrigerator at $-80^{\circ} \mathrm{C}$. Total RNA was isolated from $200 \mu \mathrm{L}$ of plasma using miRCURY RNA Isolation Kit-Biofluid (Cat No.300112, Exiqon) according to the kit procedure. Total RNA was then stored at $-80{ }^{\circ} \mathrm{C}$ until cDNA synthesis.

\section{qRT-PCR}

As much as $4 \mu \mathrm{L}$ the RNA isolated from plasma was used for cDNA synthesis using Universal cDNA Synthesis kit II, 8-64 rxns (Cat No.203301, Exiqon) according to the kit procedure. qRT-PCR was performed using ExiLent SYBR Green PCR master mix, 2.5 $\mathrm{mL}$ (Cat No. 203402, Exiqon) and specific microRNA primer (Exiqon), and cDNA template. The qRT PCR was performed using the Bio-rad Thermal Cycler CFX96 Real Time System (Bio-rad, USA). The qRTPCR reaction was performed for 40 cycles with procedure as follow : predenaturation at $95^{\circ} \mathrm{C}$ for $10 \mathrm{~min}$, followed by denaturation of $95^{\circ} \mathrm{C}$ for $10 \mathrm{sec}$, annealing, extension, and data measurement at $58^{\circ} \mathrm{C}$ for $1 \mathrm{~min}$. Melting curve and melt peak curve analysis were performed to determine the specificity of the PCR product. method was used to measure miR-200c expression on plasma of HCC compared to healthy subjects with miR-16 used as reference gene in relative quantification of miR-200c expression.

Quantification of VEGF-A mRNA expression was performed by the One-Step qRT-PCR method using Bioline One-Step qRT-PCR master mix kit, VEGF-A mRNA 
primer set (forward and reverse), RNA sample according to the kit procedure. was used to calculate the relative quantification of VEGF-A mRNA expression between plasma of hepatocellular carcinoma patients and healthy subjects. Beta actin mRNA
(ACTB) was used as a reference gene for quantification of VEGF-AmRNA expression. The primer sequences of VEGF-A mRNA and ACTB mRNA used in this study were shown in TABLE 1.

TABLE 1. Primersequence for mRNA VEGF-A and mRNA ACTB

\begin{tabular}{llll}
\hline \multicolumn{1}{c}{ Gen } & \multicolumn{1}{c}{ Forward } & \multicolumn{1}{c}{ Reverse } & Product length \\
\hline VEGF-A & 5'TGCAGATTATGCGGATCAAACC3' & 5'TGCAATCACATTTGTTGTGCTGTA3' & $80 \mathrm{bp}$ \\
ACTB & 5'GGGAATTCAAAACTGGAACGGT- & 5'GGAAGCTTATCAAAGTCCTCGGCCA- & $136 \mathrm{bp}$ \\
& GAAGG3' & CA3' & \\
\hline
\end{tabular}

Expression analyzers miR-200c and VEGF-AmRNAs used Biorad CFX Manager TM Software to determine the value of quantification cycle $(\mathrm{Cq})$, amplification curve, melting curve, melt peak curve from qRT-PCR results. The expression changes of miR-200c and VEGF mRNA in plasma of HCC patients and healthy subjects were calculated using the Livak Method formula.

\section{Statistical analysis}

Data were presented as mean \pm standard deviation (SD). Unpaired t-test was used to evaluate the differences of miR-200c and VEGF-A mRNA expressions between HCC patients and healthy subjects. One way Anova were used for more than 2 groups of sub-analyzes of respondents' clinical characteristics included age, history of cirrhosis, history of $\mathrm{HBV}$ infection, $\mathrm{HCV}$ infection and BCLC stage. The correlation between miR-200c expression with VEGF-A mRNA expression was analyzed using Pearson correlation analysis. $p$ value $<0.05$ and $95 \%$ confidence interval (CI) was considered significant.

\section{RESULTS}

\section{Relationship between expression of miR-200c with characteristics and clinicopathology of HCC patients}

Relationship between expressions of miR-200c based on clinicopathological characteristic of HCC patient was presented in TABEL 2.

TABLE 2. Relationship between expressions of miR-200c based on clinicopathological characteristic of HCC patient

\begin{tabular}{lccc}
\hline \multicolumn{1}{c}{ Characteristic } & \multicolumn{2}{c}{ HCC } & \\
\cline { 2 - 3 } & $\mathrm{n}$ & $\begin{array}{c}\text { Expression of miR- } \\
\text { 200c (Mean } \pm \text { SD) }\end{array}$ & p-Value \\
\hline Age $(\mathrm{n}=36)$ & 7 & & \\
$\bullet \quad \leq 50$ & 6 & $9.90 \pm 1.53$ & 0.057 \\
$-\quad>50$ & & & \\
BCLC stage $(\mathrm{n}=29)$ & 3 & $9.54 \pm 1.75$ & 0.679 \\
- Early stage & 8 & $9.11 \pm 1.38$ & \\
\hline$\quad$ Advance stage & & & \\
\hline
\end{tabular}




\section{Gender $(\mathrm{n}=36)$}

- Male

- Female

$$
8.80 \pm 1.94
$$

Smoking history $(\mathrm{n}=29)$

- Yes

- No

$$
\begin{aligned}
& 9.99 \pm 0.93 \\
& 8.94 \pm 1.50
\end{aligned}
$$

Alcohol consumption $(\mathrm{n}=29)$

- Yes

- No

$$
\begin{gathered}
7.95 \pm 0 \\
9.36 \pm 1.41
\end{gathered}
$$

Hepatitis $(\mathrm{n}=33)$

- Yes

- No

Cirrhosis hepar $(\mathrm{n}=29)$

- Yes

- No

$\operatorname{AFP}(\mathrm{ng} / \mathrm{ml})(\mathrm{n}=31)$

- $<200$

- $>200$

Nodul ( $\mathrm{n}=28)$

- Single

- Multiple

TACE $(\mathrm{n}=29)$

- Pre

- Post

4

7

Metastasis $(\mathrm{n}=32)$

- Yes

- No

$$
\begin{aligned}
& 8.86 \pm 1.91 \\
& 9.00 \pm 1.60
\end{aligned}
$$$$
0.896
$$

$8.61 \pm 1.21$

$9.46 \pm 1.48$

$9.29 \pm 1.60$

0.476

$8.55 \pm 1.89$

$8.42 \pm 2.14$

0.419

7

$9.28 \pm 1.40$

$9.62 \pm 1.74$

$9.00 \pm 1.28$

0.512

$7.52 \pm 1.62$

$0.038^{*}$
The miR-200c expression showed significantly deference between the metastasis groups compared to the nonmetastatic group $(p<0.05)$. The relative expression of miR-200c in the metastasis group $(\Delta \mathrm{Cq}=7.52 \pm 1.62)$ was significantly higher than the relative expression of miR$200 \mathrm{c}$ in the non-metastatic group $(\Delta \mathrm{Cq}=9.62$ \pm 1.34 ). However, the relative expression of miR-200c did not differ significantly on the basis of other sociodemographic and clinicopathologic characteristics.

\section{Expression of microRNA-200c in blood plasma of HCC patient and healthy subject}

To evaluate the factors that influence the loss of miR-200c expression on blood plasma of HCC patients, a logistic regression analysis was performed based on sociodemographic and clinicopathologic characteristics as shown in TABLE 3. 
TABLE 3. Logistic regression analysis of miR-200c expression that detected and undetected in blood plasma of HCC patients $(n=36)$

\begin{tabular}{lcllrrrrr}
\hline & & & & & & \multicolumn{3}{c}{$85 \%$ C.I $\operatorname{Exp}(\mathrm{B})$} \\
\multicolumn{1}{c}{ Parameter } & B & Stand. err & Wald & df & Sig & Exp(B) & Lower & Upper \\
\hline HBV & -3.047 & 1.648 & 3.417 & 1 & 0.065 & 0.047 & 0.002 & 1.201 \\
Multiple nodul & -0.761 & 0.654 & 1.35 & 1 & 0.245 & 0.467 & 0.130 & 1.684 \\
\hline
\end{tabular}

The variables in the equation of independent variables, $p$ value of wald test had significance $>0.25$. Those value of $\mathrm{HBV}$ $(\mathrm{p}=0.065)$ and nodule $(\mathrm{p}=0.245)$ meant that each variable of HBV and nodule had significant partial influence to loss of miR- 200c expression on HCC patients. The quantification results of the fold change expression miR-200c in the blood plasma of HCC patients compared to blood plasma of healthy subjects shown in TABLE 4.

TABLE 4. Relative expression of miR-200c in the blood plasma of hepatocellular carcinoma patient compared to healthy subject $(n=26)$

\begin{tabular}{|c|c|c|c|}
\hline Sampel & $\Delta \mathrm{Cq} \operatorname{miR}-200 \mathrm{c}(\mathrm{Mean} \pm \mathrm{SD})$ & $\Delta \Delta \mathrm{Cq}$ miR-200c & Fold Change $\left(2^{-\Delta \Delta \mathrm{Cq}}\right)$ \\
\hline $\mathrm{HCC}(\mathrm{n}=13)$ & $8.75 \pm 1.75$ & \multirow{2}{*}{0.89} & \multirow{2}{*}{0.53} \\
\hline Healthy subject $(n=13)$ & $7.8 \pm 2.11$ & & \\
\hline
\end{tabular}

The value of $2^{-\Delta \Delta \mathrm{Cq}}$ was less than $1(0.53)$, then the calculation of fold change was continued by using the calculation with the result of 1.85 . It could be concluded that the miR-200c expression in the blood plasma of HCC patients was down regulated 1.85-fold compared to that of healthy subjects.
The difference of relative expression $(\Delta \mathrm{Cq})$ miR-200c plasma between HCC patients and healthy subjects was showed by TABLE 5. No significant difference in the relative expression of miR-200c in the blood plasma between HCC patients and healthy subjects was observed $(\mathrm{p}>0.05)$.

TABLE 5. Comparison test between relative expression of miR-200c in the blood plasma of HCC patients and healthy subjects $(n=26)$

\begin{tabular}{lcc}
\hline \multicolumn{1}{c}{ Group } & $\Delta$ Cq miR-200c (Mean \pm SD) & $\mathrm{p}$ \\
\hline HCC $(\mathrm{n}=13)$ & $8.75 \pm 1.75$ & $0.258^{*}$ \\
Healthy subject $(\mathrm{n}=13)$ & $7.6 \pm 2.11$ & \\
\hline
\end{tabular}

\section{Expression of mRNA VEGF-A in blood plasma of HCC patients and healthy subjects}

The expression of mRNA VEGF-A in blood plasma of HCC patients and healthy subjects was showed in TABLE 6. The expression of VEGF-A mRNA in the blood plasma of HCC patients increased 4.42 fold compared to healthy subjects. 
TABLE 6. Relative expression of mRNA VEGF-A in the blood plasma of HCC and healthy subjects $(n=72)$

\begin{tabular}{lccc}
\hline \multicolumn{1}{c}{ Group } & $\Delta$ Cq mRNA VEGF $($ Mean \pm SD $)$ & $\Delta \Delta$ Cq mRNA VEGF & $2^{-\Delta \Delta \mathrm{Cq}}$ \\
\hline HCC $(\mathrm{n}=36)$ & $-0.95 \pm 1.97$ & -2.14 & \multirow{2}{*}{4.42} \\
Healthy subject $(\mathrm{n}=36)$ & $1.19 \pm 1.80$ & & \\
\hline
\end{tabular}

The difference in the relative expression $(\triangle \mathrm{Cq})$ of VEGF-A mRNA between HCC patients and healthy subject showed in TABLE 7. A significant difference in relative expression $(\triangle \mathrm{Cq})$ of VEGF mRNA between blood plasma of HCC patients and healthy subjects was observed $(p<0.001)$. The lower the $\Delta \mathrm{Cq}$ value, the higher the mRNA expression. It can be interpreted that the relative expression of mRNA VEGF-A was significantly upregulated in plasma of HCC patients compared to that in healthy subjects.

TABLE 7. Comparison test between relative expression of mRNA VEGF-A in the blood plasma of HCC and healthy subject $(n=72)$

\begin{tabular}{llc}
\hline \multicolumn{1}{c}{ Group } & $\Delta$ Cq mRNA VEGF $($ Mean \pm SD) & $\mathrm{P}$ \\
\hline HCC $(\mathrm{n}=32)$ & $-0.95 \pm 1.97$ & $<0.001^{*}$ \\
Healthy subject $(\mathrm{n}=25)$ & $1.19 \pm 1.80$ & \\
\hline
\end{tabular}

\section{Correlation between expression miR-200c and VEGF-A mRNA in blood plasma}

TABLE 8 shows the correlation between miR-200c expression and VEGF-A mRNA expression in HCC patients and healthy subjects. The relative expression of miR$200 \mathrm{c}$ in blood plasma of HCC patients ( $p$ $=0.576)$ and also in healthy subjects $(\mathrm{p}=$ 0.874 ) were not correlated with the relative expression of VEGF-A mRNA. However, it appeared that the relative expression of miR200c and VEGF-A mRNA had a negative correlation. It shown that the lower the relative expression of miR-200c, the higher the relative expression of VEGF-A mRNA was observed. Furthermore, the higher the relative expression miR-200c, the lower the relative expression of VEGF-A mRNA was observed.

TABLE 8. Correlation between miR-200c expression and VEGF-A mRNA expression

\begin{tabular}{lcccc}
\hline Variable & \multicolumn{2}{c}{$\begin{array}{c}\Delta \text { Cq mRNA VEGF-A } \\
\text { (mean } \pm \text { SD) }\end{array}$} & p \\
\hline \multirow{2}{*}{$\Delta$ Cq miR-200c } & HCC & HCC & \\
& $8.75 \pm 1.75$ & $-0.95 \pm 1.97$ & 0.576 & -0.171 \\
$($ mean \pm SD) & Healthy subject & Healthy subject & & \\
& $7.86 \pm 2.11$ & $1.19 \pm 1.8$ & $0.874-0.049$ \\
\hline
\end{tabular}




\section{DISCUSSION}

Hepatocellular carcinoma development takes a long time with accumulation changes in the genetic and epigenetic levels that lead to oncogenes activation or inactivation of tumor suppressor genes. In terms of sex, the majority of HCC patients were males as many as 23 people and females as many as 13 people which mean having a 2:1 ratio with only one of the most dominant risk factors is the majority of HCC patients infected with hepatitis B virus. The HCC patients with various risk factors such as being in endemic areas of hepatitis, alcoholics, smokers, cirrhosis, aflatoxin contamination and age, male and female comparison rates to $4: 1 .^{15}$ The dominance of male HCC patients is in line with the high mortality rate of $\mathrm{HCC}$ patients that majority is males in pacific Asia. The dominant age range of HCC patients in both men and women was $\geq 50$ years age group (69.4\%). In addition, the incidence of HCC in Asia-pacific increased both men and women aged $\geq 40$ years. ${ }^{16}$

The HCC patients in this study were diagnosed at an early stage (BCLC B) of 9 people $(32.7 \%)$ and advanced stage (BCLC $\mathrm{C}$ and BCLC D) were $20(52.6 \%)$. In this study, no HCC patients were diagnosed with BCLC A stage. At very early stage of HCC, one-third of patients showed no specific symptoms when examined and only a quarter complained of discomfort and abdominal pain. Advanced stages are characterized by the presence of extra hepatic spread, vascular invasion, and the presence of cancer-related symptoms. ${ }^{17}$

In this study, the majority of $\mathrm{HCC}$ patients were also positively infected with the hepatitis B virus. The hepatitis B is the most dominant risk factor for $\mathrm{HCC}$ cases. Approximately $60-80 \%$ of people with hepatitis B infection developed into HCC in Asia. ${ }^{18}$ In Indonesia as one of the developing countries in Asia, the incidence of HBV infection is at a high percentage of about $8 \%$ of the population. ${ }^{19}$ In this study the incidence of cirrhosis only 9 people (31\%) the rest of the results of the examination did not contain cirrhosis. In theory, about $80 \%$ to $90 \%$ of patients with cirrhosis can developed into HCC. Patients with chronic hepatitis B infection accompanied by cirrhosis may continue to develop into $\mathrm{HCC}$, especially patients with hepatitis $\mathrm{B}$ virus that actively replicate. ${ }^{20}$

The majority of HCC patients experienced an increase in alpha fetoprotein (AFP) concentrations higher than the normal limit $(\geq 200 \mathrm{ng} / \mathrm{mL})$. The high AFP concentrations in HCC patients are associated with HCC patient status with hepatitis viral infection, especially hepatitis B virus. The upregulation and downregulation of AFP expression are closely related to BCLC status of HCC patients where in the early stages BCLC (O-A) concentration of AFP in normal limits. ${ }^{21}$ The study also looked at demographic and clinicopathologic characteristics that affected the loss of miR200 c expression in 17 plasma samples of HCC patients using logistic regression. The HBV infection variable and the number of nodules have a significant partial effect on the loss of miR-200c expression in HCC. The loss of miR-200c expression in blood plasma of HCC patients was also reported by Okamoto et al. ${ }^{22}$ where HCV and HBV were known to regulate microRNA expression through epigenetic mechanisms by the occurrence of DNA hypermethylation in many gen promoters. Specific mechanisms of how the regulation of miR-200c expression was reported by Vrba et al. ${ }^{23}$ In their study of DNA methylation of miR-200c and miR-141 in $\mathrm{CpG}$ islands causing loss of expression miR-200c which is a class of suppressor tumors microRNAin cancer.

Multiple nodules in HCC patients may be derived from multiple primary HCC nodules and metastatic intrahepatic nodules. Research conducted by $\mathrm{Ng}$ et al. $^{24}$ in $\mathrm{HCC}$ patients with multiple nodules found $36 \%$ of primary nodules and $64 \%$ of intrahepatic metastatic nodules. Previous studies have revealed that the miR-200 family has been shown to suppress the formation and growth of HCC cancer cells. In vitro study using melanoma cells revealed increased expression of miR- 
200c and miR-205 capable of inhibiting cancer formation. ${ }^{25}$ To support the growth of cancer cells requires angiogenesis activation for the formation of new blood vessels. The miR-200c is a negative regulator of VEGF expression at mRNA and protein levels. ${ }^{26} \mathrm{In}$ studies using ovarian cancer cells, miR-200c suppresses the expression of fas-associated phosphatase-1 (FAP-1), thus increasing the expression of CD95 which is an apoptotic receptor, thus increasing the sensitivity of cells to apoptosis. ${ }^{27}$

This study found that the relative expression of miR-200c in the blood plasma of HCC patients experienced downregulation of 1.85 times compared to that expression in healthy subjects. Previous studies have found that miR-200c expression in HCC tissues was downregulated compared to healthy tissue. ${ }^{6,10}$ Research using circulating microRNA from serum HCC patients miR-200c is known to decrease expression than healthy individuals although not significantly different. ${ }^{28}$ This suggests that decreased expression of miR$200 \mathrm{c}$ is one of the molecular mechanisms of the carcinogenesis process. The miR200 family including miR-200c is a tumor suppressor microRNA, where its down regulation or loss of expression contributes to the process of carcinogenesis and cancer progression with increased expression of the oncogenic protein. ${ }^{10}$ Research conducted by Li et al. ${ }^{29}$ found that decreased miR-200c expression in HCC tissue and line-cell was associated with increased oncogen mitotic arrest deficiency protein 2 (MAD2L). Down regulation of miR-200c expression in cancer cells contributes to the epithelial mesenchymal transition (EMT) process, migration, metastasis by direct targeting of E-cadherin mRNA to inhibit transcription pathways from ZEB1 and ZEB2. ${ }^{30}$

MicroRNA deregulation, especially microRNA downregulation can be due to interference of microRNA biogenesis process in cancer cell. Melo et al. ${ }^{31}$ revealed that mutations in the exportin-5 gene (XPO5) result in trapping of pre-miRNAs in the nucleus thus inhibiting the maturation of microRNAs in cancer cells. This study found the relationship between relative expression miR-200c with metastatic status of HCC patients. Metastasis is the spread of cancer cells originating from primary cancer tissue to the nearest organ or tissue of distant organs through blood vessels and lymphatic vessels. ${ }^{32}$ The miR-200c is known to regulate many genes that support angiogenesis, invasive, and metastasis. The VEGF-A, DLC1, ZEB1/ZEB2, FLT-1, KDR, VIM, PLCG1, NTRK2, NTF3, FN1, MSN genes are regulated by miR-200c proven to play a role in cancer progression..$^{33}$ Panda et al. ${ }^{34}$ reported how miR-200c regulates the expression of VEGF-A. using ishikawaline cells (endometrial adenocarcinoma) increased miR-200cexpression followed by decreased expression of $m$ RNA and VEGF-A protein. VEGF-A is a protein that plays an important role in the process of angiogenesis early in the development of cancer cells by supporting neovascularization of cancer tissue.

Deleted liver cancer-1 (DLC1) is a tumor suppressor gene and metastasis suppressor gene that govern the formation of actin and focal adhesion. The expression of DLC1 is also regulated by miR-200c. ${ }^{35}$ miR-200c also suppresses the expression of fibronectin 1 (FN1), meosin (MSN), and leptin receptor (LEPR) so that cancer cell migration becomes inhibited. ${ }^{36}$ miR-200c is found to regulate the epithelial to mesenchymal transition process that supports metastasis with direct targeting mechanisms ZEB1 and ZEB2 to suppress E-cadherin. ${ }^{36}$ In this study, the relative expression of VEGF-A mRNA was significantly upregulated in blood plasma of HCC patients by 4.42 fold compared to that in healthy subjects. This is consistent with the results in the previous studies that found that VEGF-A mRNA expression has increased in HCC tissue compared to normal tissue and is strongly associated with vascularization of cancer and mortality incidence. ${ }^{37} \mathrm{HCC}$ patients with hepatitis $B$ virus infection have increased VEGF-A mRNA expression and this correlates with recurrence after resection and mortality events in HCC patients. ${ }^{38}$

The correlation test results showed 
that the relative expression of miR-200c was not significantly correlated with the relative expression of VEGF-A mRNA both in the blood plasma of HCC patients and of healthy subjects. In this study was found that miR-200c has the ability to regulate the expression of many protein coding genes, one of which is the VEGF-A gene. MicroRNA has the potential to regulate the expression of hundreds of genes, and one protein coding gene can be regulated by various microRNA. These contributions resulting many pathways to be cancer cells. There are currently over 1000 genes encoding microRNAs in the human genome, and the microRNAs play a role in regulating the expression of about $60 \%$ of the human protein coding gene. ${ }^{39}$

Not only the expression of miR200c regulated by many factors but also the expression of VEGF-A mRNA. The miR200b expression in cancer cells is also known as the VEGF-A regulator by targeting VEGF-A directly and its receptor Flt 1 and KDR. In experiment miR200b may act as an angiogenesis inhibitor in cancer cells. ${ }^{40}$ This opinion is in agreement with Yeh et $a l .{ }^{10}$ found that 4 families of miR200 (miR-200a, miR-200b, miR-200c, and miR-141) acting as suppressor tumor genes decreased expression in HCC. Cancer cells in hypoxic conditions have increased regulation of VEGF expression for the purpose of angiogenesis. In experiment miR-20b is known to decrease the regulation of VEGF expression in cancer cells. MiR$20 \mathrm{~b}$ targeted directly at 3'UTR VEGF plays a role in regulating VEGF protein expression in cancer. MiR-125a directly regulates the expression of the VEGF-A gene at post transcription level by targeting the VEGF-A30 mRNA. In their experiment with restore the expression of miR-125a, it was able to inhibit the development of cancer malignancy significantly by decreasing the regulation of matrix metalloproteinase 11 (MMP11) and VEGF-A expression both in vitro and in vivo. ${ }^{41}$ The presence of many other more dominant regulators in regulating VEGF-A gene expression besides miR-200c led to variations in the quantification results of relative expression of the two genes so no correlation was found between the relative expression of miR-200c and VEGF-A mRNA in blood plasma of HCC patients.

\section{CONCLUSION}

This study shows that the expression of miR-200c and VEGF-A mRNA can be detected and quantified in the blood plasma of HCC. There is a downregulation of miR-200c expression and upregulation of VEGF-A mRNA expression between plasma of HCC patients compared to that healthy subjects. However, there is no significant correlation between miR-200c expression and VEGF-A mRNA expression in the blood plasma of HCC patients.

\section{ACKNOWLEDGMENTS}

We would like to thanks for the patients who participate in this study. We also would like to thanks for Dr. Sardjito General Hospital Yogyakarta and Prof. DR. Margono Soekarjo General Hospital Purwokerto to facilitate this study for sample access.

\section{REFERENCES}

1. Ferlay J, Colomber M, Soerjomataram I. Global and regional estimates of the incidence and mortality for 8 cancers: Globocan 2018. Lyon: International Agency for Research on Cancer/World Health Organization; 2018.

2. Gomaa AI, Khan SA, Leen EL, Waked I. Taylor-Robinson SD. Diagnosis of hepatocellular carcinoma. World J Gastroenterol 2009; 15(11):1301-14.

3. Omata M, Lesmana LA, Tateishi R, Chen PJ, Lin SM, Yoshida H, et al. Asian Pacific Association for the Study of the Liver consensus recommendations on hepatocellular carcinoma. Int Hepatol 2010; 4(2):439-74. http://dx.doi.org/10.1007/s12072-010-9165-7

4. Croce CM. Causes and consequences of microRNA dysregulation in cancer. Nat 
Rev Genet 2009; 10(10):704-14. http://dx.doi.org/10.1038/nrg2634

5. Wong CM, Wong CC, Lee JM, Fan DN, $\mathrm{Au}$ SL, Ng IO. Sequential alterations of microRNA expression in hepatocellular carcinoma development and venous metastasis. Hepatology 2012; 55(5):1453-61. http://dx.doi.org/10.1002/hep.25512

6. Murakami Y, Yusada T, Saigo K, Urashima T, Toyoda H, Okanoue T, et al. Comprehensive analysis of microRNA expression patterns in hepatocellular carcinoma and non-tumorous tissues. Nature 2006; 25(54):2537-45.

http://dx.doi.org/10.1038/sj.onc.1209283

7. Bartel DP. MicroRNAs: genomics, biogenesis, mechanism, and function. Cell 2004; 116(2):281-97.

8. Anwar S, Lehmann U. MicroRNAs: Emerging novel clinical biomarkers for hepatocellular carcinomas. J Clin Med 2015; 4(8):1631-50.

http://dx.doi.org/10.3390/jcm4081631

9. Huang $\mathrm{S}, \mathrm{He} \mathrm{X}$. The role of microRNAs in liver cancer progression. Br J Cancer 2011; 104(2):235-40.

http://dx.doi.org/10.1038/sj.bjc.6606010

10. Yeh TS, Wang F, Chen TC, Yeh CN, Yu MC, Jan YY, et al. Expression profile of microRNA-200 family in hepatocellular carcinoma with bile duct tumor thrombus. Ann Surg 2014; 259(2):346-54.

http:/dx.doi.org/10.1097/SLA.0000000000000223

11. Panda H, Pelakh L, Chuang TD, LouX, Bukulmez O, Chegini N. Endometrial miR-200c is altered during transformation into cancerous states and targets the expression of ZEBs, VEGFA, FLT1, IKK $\beta$, KLF9, and FBLN5. Reprod Sci 2012; 19(8):786-96.

http://dx.doi.org/10.1177/1933719112438448

12. Shibuya M. Vascular endothelial growth factor (VEGF) and its receptor (VEGFR) signaling in angiogenesis: a crucial target for anti- and pro-angiogenic therapies. Genes Cancer 2011; 2(12):1097-105. http://dx.doi.org/10.1177/1947601911423031

13. Ferrara N, Gerber HP, LeCouter J. The biology of VEGF and its receptors. Nat Med 2003; 9(6):669-76. http://dx.doi.org/10.1038/nm0603-669

14. Cao G, Li X, Qin C, Li J. Prognostic value of VEGF in hepatocellular carcinoma patients treated with sorafenib: a metaanalysis. Med Sc Monit 2015; 21:3144-51.

15. Yang JD, Roberto LR. Hepatocellular carcinoma: a global view. Nat Rev Gasterol Hepatol 2014; 7(8):448-58.

http://dx.doi.org/10.1038/nrgastro.2010.100

16. Zhu RX, Seto WK, Lai CL, Yuen MF. Epidemiology of hepatocellular carcinoma in the asia-pacific region. Gut Liver 2016;10(3):332-9. http://dx.doi.org/10.5009/gnl15257

17. Goh KL, Razlan H, Hartono JL, Qua CS, Yoong BK, Koh PS, et al. Epidemiology and clinical presentation in a multiracial Asian population. J Dig Dis 2015; 16(3):152-8. http://dx.doi.org/10.1111/1751-2980.12223

18. Abbas Z \& Siddiqui AR. Management of hepatitis B in developing countries. World J Hepatol 2011; 3(12):292-9. http://dx.doi.org/10.4254/wjh.v3.i12.292

19. Yano Y, Utsumi T, Lusida MI, Hayasi Y. Hepatitis $B$ virus infection in Indonesia. World $\mathrm{J}$ Gastroenterol 2015; 21(38):10714-20. http://dx.doi. org/10.3748/wjg.v21.i38.10714

20. Peng CY, Chien RN, Liaw YF. Hepatitis $\mathrm{B}$ virus-related decompensated liver cirrhosis: benefits of antiviral therapy. J Hepatol 2012; 57(2):442-50. http://dx.doi.org/10.1016/j.jhep.2012.02.033

21. Zhang XF, Qi X, Meng B, Liu C, Yu L, Wang B, et al. Prognosis evaluation in alpha-fetoprotein negative hepatocellular carcinoma after hepatectomy: comparison of five staging systems. Eur J SurOncol 2010; 36(8):718-24. http://dx.doi.org/10.1016/j.ejso.2010.05.022

22. OkamotoY, ShinjoK, Shimizu Y, Sano T, Yamao K, Gao W, et al. Hepatitis virus infection affects DNA methylation in mice with humanized liver. Gastroenterology 2014; 146(2):562-72. http://dx.doi.org/10.1053/j.gastro.2013.10.056

23. Vrba L, Jensen TJ, Garbe JC, Heimark RL,Cress AE, Dickinson S. Role for DNA methylation in the regulation of miR- 
200c and miR-141 expression in normal and cancer cells. PLoS One 2010; 5(1):8697. http://dx.doi.org/10.1371/journal.pone.0008697

24. Ng IO, Guan XY, Poon RT, Fan ST, Lee JM. Determination of the molecular relationship between multiple tumour nodules in hepatocellular carcinoma differentiates multicentric origin from intrahepatic metastasis. J Pathol 2003; 199(3): 345-53.

http://dx.doi.org/10.1002./path.1287

25. Xu Y, Brenn T, Brown ERS, Doherty V, Melton DW. Differential expression of microRNAs during melanoma progression: miR-200c, miR-205 and miR-211 are downregulated in melanoma and act as tumour suppressors. Br J Cancer 2011; 106: 553-61

26. Hu TX, Wang G, Guo XJ, Sun QQ, He P, $\mathrm{Gu} \mathrm{H}$, et al. MiR 20a,-20b and -200c are involved in hydrogen sulfide stimulation of VEGF production in human placental trophoblasts. Placenta 2016; 39: 101-10. http://dx.doi.org/ 10.1016/j.placenta.2016.01.019

27. Schickel R, Park S, Murmann AE, Peter ME. mir-200c regulates induction of apoptosis through CD95 by Targeting FAP-1. Molecular Cell 2010; 38(6):908-15. https://doi.org/10.1016/j.molcel.2010.05.018

28. Dhayat SA, Husing A, Senniger N, Schmidt N, Haier J, Wolters $\mathrm{H}$, et al. Circulating microRNA-200 family as diagnostic marker in hepatocellular carcinoma. PLoS One 2015; 10(10):0140066. http://dx.doi.org/10.1371/journal.pone.0140066

29. Li Y, Bai W, Zhang J. MiR-200c-5p suppresses proliferation and metastasis of human hepatocellular carcinoma (HCC) via suppressing MAD2L1. Biomed Pharmacother 2017; 92:1038-44. http://dx.doi.org/10.1016/j.biopha.2017.05.092

30. Park SM, Gur AB, Legyel E,Peter ME. The miR-200 family determines the epithelial phenotype of cancer cells by targeting the E-cadherin repressors ZEB1 and ZEB2. Genes Dev 2008; 22(7):894-907.

http://dx.doi.org/10.1101/gad.1640608
31. Melo SA, Moutinho C, Ropero S, Calin GA, Rossi S, Spizzo R, et al. A genetic defect in exportin-5 traps precursor microRNAs in the nucleus of cancer cells. Cancer Cell 2010; 18(4):303-15. http://dx.doi.org/10.1016/j.ccr.2010.09.007

32. Wan L, Pantel K, Kang Y. Tumor metastasis: moving new biological insights into the clinic. Nat Med 2013; 19(11):1450-64. http://dx.doi.org/10.1038/nm.3391

33. Sulaiman SA, Ab Mutalib NS, Jamal R. miR-200c regulation of metastases in ovarian cancer: potential role in epithelial and mesenchymal transition. Front Pharmacol 2016; 7:271. http://dx.doi.org/10.3389/fphar.2016.00271

34. Panda H, Pelakh L, Chuang TD, Lou X, Bukulmez O, Chegini N. Endometrial miR-200c is altered during transformation into cancerous states and targets the expression of ZEBs, VEGFA, FLT1, IKK $\beta$, KLF9, and FBLN5. Reprod Sci 2012; 19(8):786-96. http://dx.doi.org/10.1177/1933719112438448

35. Feng X, Li C, Liu W, Chen H, Zhou W, Wang L, et al. DLC-1, a candidate tumor suppressorgene, inhibits the proliferation, migration and tumorigenicity of human nasopharyngeal carcinoma cells. Int J Oncol 2013; 42(4):1973-84. http://dx.doi.org/10.3892/ijo.2013.1885

36. Howe EN, Cochrane DR, Richer JK. Targets of miR-200c mediate suppression of cell motility and anoikis resistance. Breast Cancer Res 2013; 13(2):45. http://dx.doi.org/10.1186/bcr2867

37. Jeng KS, Sheen IS, Wang YC, Gu SL, Chu CM, Shih SC, et al. Is the vascular endothelial growth factormessenger RNA expression in resectable hepatocellular carcinoma of prognostic value after resection? World J Gastroenterol 2004; 10(5):676-81.

38. Moon WS, Rhyu KH, Kang MJ, Lee DG, Yu HC, Yeum JH, et al. Overexpression of VEGF and angiopoietin 2: a key to high vascularity of hepatocellular carcinoma? Mod Pathol 2003;16:552-557.

39. Menor M, Ching Travers, Zhu X, 
Garmire D, Garmire LX. mirMark: a site-level and UTR-level classifier for miRNA target prediction. Genome Biol 2014; 15(10):500. http://dx.doi.org/10.1186/s13059-014-0500-5 40. Choi YC, Yoon S, Jeong Y, Yoon J, Baek $\mathrm{K}$. Regulation of vascular endothelial growth factor signaling by miR-200b. Mol cell 2011; 32(1):77-82. http://dx.doi.org/10.1007/s10059-011-1042-2

41. Bi Q, Tang S, Xia L, Du R, Fan R, Gao $\mathrm{L}$, et al. Ectopic expression of MiR-125a inhibts the proliferation and metastasis of hepatocellular carcinoma by targeting MMP11 and EGF. PLoS One 2012; 7(6):e40169.

http://dx.doi.org/10.1371/joumal.pone.0040169. 